\title{
博多湾における「高度な栄養塩管理手法」 の一考察
}

\author{
後藤 祐哉 ${ }^{1} \cdot$ 横山 佳裕 $^{2} \cdot$ 内田 唯史 ${ }^{3}$ ・ 中嶋 雅孝 4 \\ 1 （一財）九州環境管理協会（厂813-0004 福岡県福岡市東区松香台一丁目 10-1） \\ E-mail: goto@keea.or.jp \\ 2正会員 （一財）九州環境管理協会（８ 813-0004 福岡県福岡市東区松香台一丁目 10-1） \\ 3正会員 (一財) 九州環境管理協会（８８13-0004 福岡県福岡市東区松香台一丁目 10-1） \\ 4 (一財) 九州環境管理協会（厂 813-0004 福岡県福岡市東区松香台一丁目 10-1)
}

\begin{abstract}
本研究では, 夏季に扔ける内部生産の抑制による生物生息環境の保全, 冬季におけるリン不足による色 落ちが懸念されているノリやワカメをはじめとした生物生産の健全化を目的とした栄養塩管理手法を検討 するため, 博多湾に扔ける栄養塩類負荷量の変動に伴う海域濃度変動の試算を行った。 その結果, 夏季に おいては, T-P 負荷量の削減により内部生産が抑制され, 海域 COD の低減に効果がみられた。また, 冬季 おいては, T-P 流入負荷量を 1.5 倍にすることにより, 内部生産由来の COD は増加するが, 現状濃度で環 境基準值を下回る西部海域や東部海域では環境基準值以下を維持し，ノリ，ワカメ養殖の生育環境改善の 効果がみられた。
\end{abstract}

Key Words: contorol and management of nutrient loads, advanced sewage treatment, Influx load, Hakata Bay

\section{1. はじめに}

閉鎖性水域では, 栄養塩類の過剩な供給による水 質の富栄養化，底層の貧酸素化等が問題となり，水 域保全対策として，東京湾，瀬戸内海など，88の閉 鎖性海域を対象とした窒素とリンに係わる水質環境 基準の設定及び類型指定, 污濁が著しい東京湾, 伊 勢湾，瀬戸内海の 3 海域における窒素とリンの発生 負荷量の総量規制等が行われてきた。これら水質規 制の結果, 指定水域に打ける COD や窒素, リン濃度 は低下傾向を示し, 赤潮等の発生件数も減少傾向に ある11.

一方, 窒素やリンは, 生物生産に直接関与する重 要な物質であるため, これら負荷量の減少に伴う海 域の生物生産力の低下が懸念されている ${ }^{1)}$ 。例えば, 東京湾や瀬戸内海及び有明海では, 漁獲量が以前に 比べて減少している。特に, 水域の豊富な栄養塩類 の恩恵に浴していたノリ生産への影響が著しい1． また，海域の窒素・リンの濃度やバランスが変化す ると, 植物プランクトンの出現状況にも影響を与 $亢^{22,3)}$, 瀬戸内海では T-N/ T-P 比の変化に伴う植物 プランクトンの種の変化が顕著となっている4).
このため, 現在では栄養塩類の円滑な物質循環を 目的に，環境省を中心として海域の環境と生物生産 力の向上を目指した検討が行われているところであ $ろ^{5)}$.

沿岸部に都市機能を有し，閉鎖性が強い博多湾に おいても, 福岡市をはじめとする流域市町の都市化 による流域人口の増加に伴う ${ }^{6}$, 流入負荷量の増加 によって湾内の水質污濁が顕著となった。このた め, 流入負荷量の削減を目的とした, 流域の下水道 整備や「博多湾特定水域高度処理基本計画」 ${ }^{7)}$ に基づ く, 高度処理設備の導入による下水処理水のリン除 去が急速に進められてきた ${ }^{8)}$ 。これら下水道整備率 の向上やリンの高度処理により, 博多湾では全窒素 （T-N）濃度は経年的に横ばい傾向であるのに対し， 全リン $(\mathrm{T}-\mathrm{P})$ 濃度は顕著な低下傾向を示している9 これを反映して図-1に示すように，2000 年以降の $\mathrm{T}-\mathrm{N} / \mathrm{T}-\mathrm{P}$ 比は, 西部海域の一時期を除きモル比で 30〜50 とレッドフィールド比：16 ${ }^{10)}$ の 2 倍以上と なって打り, 他海域 (有明海：20３0 $0^{11)}$, 大阪湾を除 く瀬戸内海：約 10〜30 ${ }^{4)}$ ) と比べても高い. また，図 -2, 図-3に示すように, COD は博多湾の制限因子と 考えられるリンの流入負荷量減少にもかかわらず経 


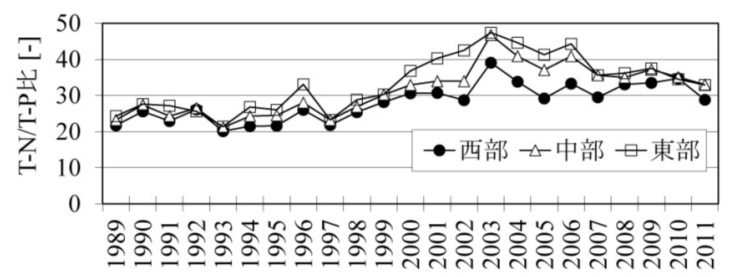

図-1 $\mathrm{T}-\mathrm{N} / \mathrm{T}-\mathrm{P}$ 比の年平均值の経年変化

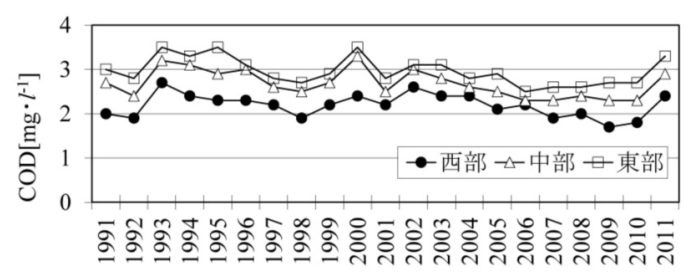

図-2 COD の年平均值の経年変化

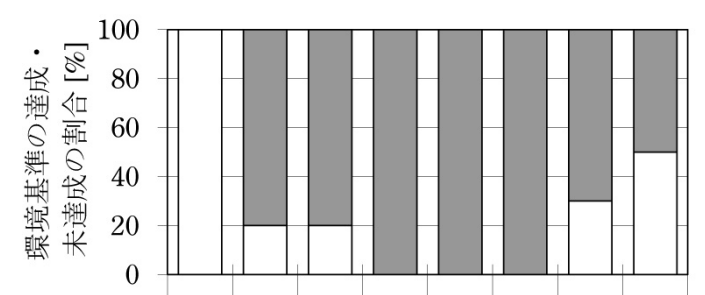

\begin{tabular}{l|l|l|l|l|l|l|l} 
W-3 & W-6 & W-7 & C-1 & C-4 & C-10 & E-2 & E-6
\end{tabular}

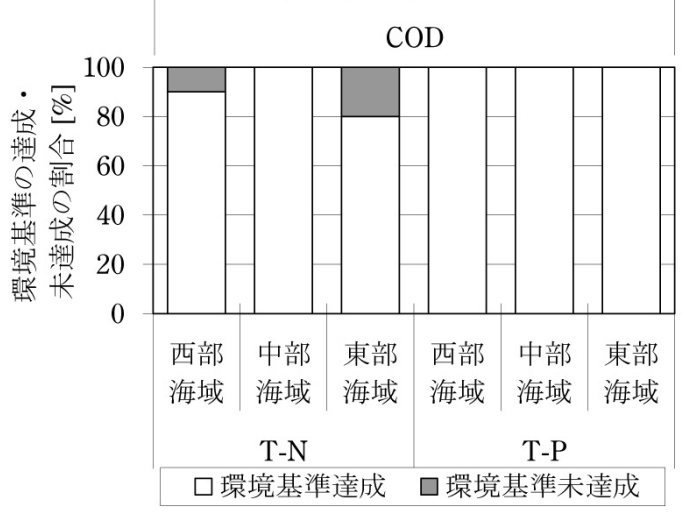

図-3 COD, T-N, T-P の環境基準の達成状況（1981～2011 年, 地点名と海域区分は図 -4 参照)

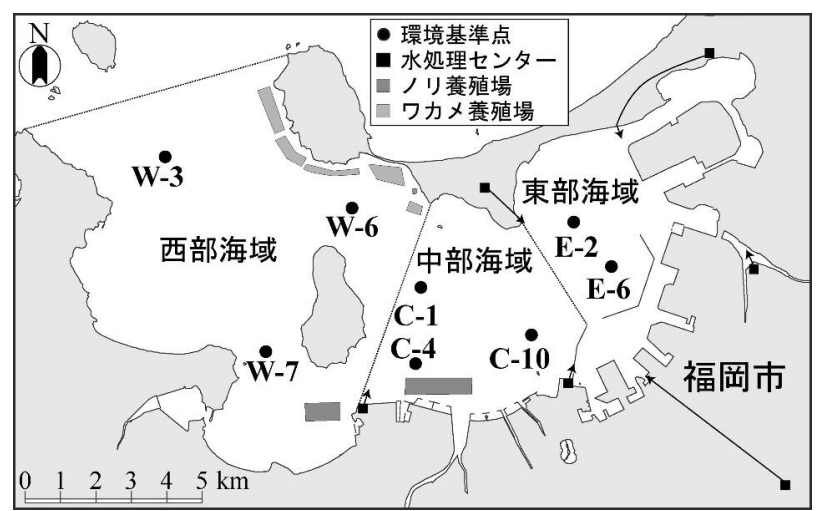

図-4 環境基準点の位置

年的な減少傾向の程度は小さく, 未だ全海域では環 境基準を達成できない.
このような博多湾の状況下, (1)夏季におけるプラ ンクトン構成種の変化による有害赤潮の発生や高い 内部生産の維持及び貧酸素水塊の発生 ${ }^{12)}$, (2)冬季に はリン不足によるノリやワカメの色落ち ${ }^{13)}$ の発生と いう 2 つ問題点が顕在化しており, 近年みられる 漁業者数の減少 ${ }^{14)}$ と相まって漁業生産量の低下が懸 念される.

これら海域環境を健全化していくためには，(1)夏 季に㧍ける内部生産の抑制による生物生息環境の保 全, (2)冬季におけるノリやワカメをはじめとした生 物生産力の向上を目指す必要がある。このためには 夏季に扔ける栄養塩類供給量の抑制, 冬季に扔ける 供給量の増加という, 季節で相反する課題を解決す ることが重要であり, そのための栄養塩類の管理手 法を確立することが必須となっている，筆者らは， これを「高度な栄養塩管理」と称している15)。

本研究では, 博多湾に扔ける環境の保全と生物生 産力の向上に向けた高度な栄養塩管理手法の確立に 向けて, まずは, 海域健全化のための栄養塩類の夏 季削減量, 冬季許容量を試算した。

\section{2. 検討方法}

栄養塩類の削減量, 許容量を試算するにあたり, 本研究においては健全な海域環境に至ることを目標 とする。健全な海域環境を示す項目として, 内部生 産量を指標する COD と内部生産に必要な栄養塩量 として博多湾の制限因子であるリンを設定し, 夏季 は COD の現状を改善すること, 冬季にはノリ・ワカ メの生長に必要なリン濃度を満たすとともに COD の現状を維持することとした。

解析対象の地点は, 図-4に示す博多湾内の環境基 準点 8 地点のうち, 外海の影響を受けやすい湾口部 の W-3 を除く 7 地点とした。解析対象期間は 1989 2010 年度の 22 年間とした.

はじめに, 博多湾への流入負荷量 ${ }^{17)}$ と $\mathrm{T}-\mathrm{N}, \mathrm{T}-\mathrm{P}$ の海域平均值の関係を西部・中部・東部海域のそれ ぞれで求めた，既存資料(6)に示されている 1992, 1997，2000，2002 年度の流入負荷量算定結果 ${ }^{6}$ をも とに,「下水処理場からの負荷」「「合流式下水処理場 からの負荷」,「その他の負荷」の 3 つの流入負荷要 因別( $\left.\left.{ }^{7)}, 16\right), 17\right)$ 下水放流量, 放流水質, 降水量 ${ }^{18)}$, 流 域土地面積 ${ }^{18)}$ から 1989〜2009 年度のそれぞれの年 平均流入負荷量を試算した。 $\mathrm{T}-\mathrm{N}, \mathrm{T}-\mathrm{P}$ 濃度には, 各 地点に打ける表層 (海面下 $0.5 \mathrm{~m}$ ), 中層（海面下 $2.5 \mathrm{~m}$ ), 底層 (海底上 $1.0 \mathrm{~m})$ の実測濃度 ${ }^{9}$ の層平均の 年平均值を海域別に平均したものを用いた。 


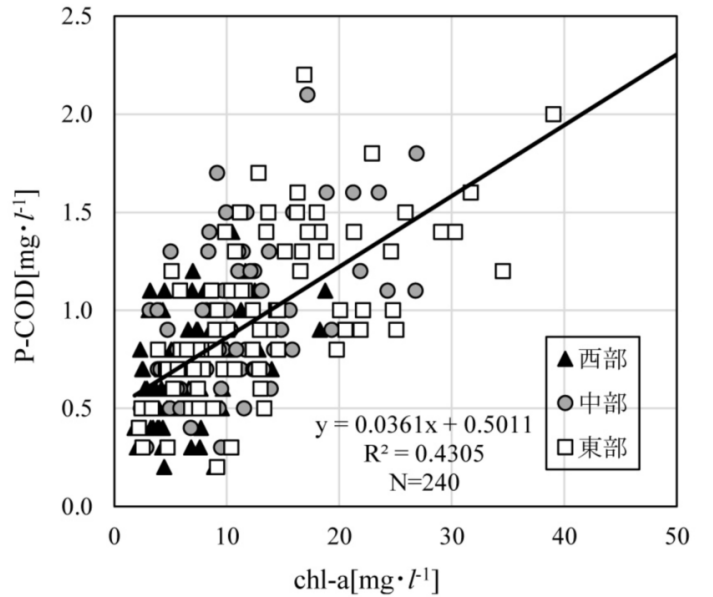

図-5 chl-a と P-COD の関係（1981〜2010 年度の全調査 結果)

次に, 懸濁態 $\mathrm{COD}(\mathrm{P}-\mathrm{COD})$ と植物プランクトン 量を指標するクロロフィル a ( chl-a) の関係（図-5) をみると，概ね正の関係にあり， P-COD の変動は chl-a の変動により增減していると考えられること から， P-COD を内部生産由来の COD と見立てた上 で, 式 (1)に示す中西ら（1994）の $\Delta \mathrm{COD}$ 法 ${ }^{20)} に よ$ り内部生産効率 $\alpha_{\mathrm{p}}$ を年別に算出し, T-N $/ \mathrm{T}-\mathrm{P}$ 比と 内部生産効率の関係を求めた。

$\mathrm{COD}=\mathrm{D}-\mathrm{COD}+\mathrm{P}-\mathrm{COD}=\mathrm{D}-\mathrm{COD}+a_{\mathrm{p}} \times \mathrm{COD}_{\mathrm{pn}}$

ここで, $\mathrm{COD}: \mathrm{COD}$ 濃度 $\left[\mathrm{mg} \cdot l^{-1}\right], \mathrm{D}^{-} \mathrm{COD}$ ：溶 解性 COD ( $\mathrm{D}-\mathrm{COD})$ 濃度 $\left[\mathrm{mg} \cdot l^{-1}\right], \mathrm{P}-\mathrm{COD}$ : 懸濁 性 $\mathrm{COD}(\mathrm{P}-\mathrm{COD})$ 濃度 $\left[\mathrm{mg} \cdot l^{-1}\right], a_{\mathrm{p}}$ : 内部生産効 率 [-], $\mathrm{COD}_{\mathrm{pn}}$ :リンあるいは窒素により内部生産可 能な $\mathrm{COD}$ の理論的最大濃度 $\left[\mathrm{mg} \cdot l^{-1}\right]$ である. COD, D-COD， P-COD には $\mathrm{T}-\mathrm{N}, \mathrm{T}-\mathrm{P}$ と同様に, 各地点に おける表層, 中層, 底層の実測濃度 ${ }^{9)}$ の層平均の年 別・海域別平均值を用いた， $\mathrm{COD}_{\mathrm{pn}}$ は式（2）より求 めた ${ }^{211}$.

$\mathrm{COD}_{\mathrm{pn}}=143 \times \min (\mathrm{T}-\mathrm{P}, \mathrm{T}-\mathrm{N} / 7.24) / 2.26$

これらの值を用いて, 流入負荷量と海域水質の関 係, $\mathrm{T}-\mathrm{N} / \mathrm{T}-\mathrm{P}$ 比と内部生産効率 $\alpha_{\mathrm{p}}$ の関係を用いて, 窒素・リンの流入負荷量を変動させた場合の, COD 濃度の值を季節別に試算した。試算結果より，栄養 塩類削減量 - 許容量を求め, 健全な海域環境の方向 性を考察した。

\section{3. 結果及び考察}

（1）栄養塩類の海域濃度及び栄養塩類の変化に伴う 内部生産効率の変化

a）栄養塩類の流入負荷量と海域濃度の関係 博多湾への $\mathrm{T}-\mathrm{P}, \mathrm{T}-\mathrm{N}$ の流入負荷量と海域別 $\mathrm{T}-\mathrm{P}$,
$\mathrm{T}-\mathrm{N}$ 濃度の関係を図-6に示す。図中に示す各海域の 流入負荷量と水質の関係式の算出にあたっては, 海 域の T-P, T-N 濃度は陸域等からの流入負荷がなけ れば, 外海水の濃度と同じとなると仮定し, 関係式 の切片は湾口部 W-3 の T-P, T-N の同期間の層別平 均濃度9)とした。

$\mathrm{T}-\mathrm{P}$ は，海域へ流入する負荷のほか，気温（水温） や底泥の有機物量等に応じて変動する溶出や波浪に 伴う底泥からの巻き上げ, 潮の干満状態といった気 象・海象状況によっても変化するため, 各海域とも にばらつきが生じているものの, 流入負荷量に概ね 比例して変動している状況がうかがえる。また，湾 への負荷は, 全体の約 7 割が東部海域に流入するこ とから ${ }^{7)}$, 東部海域での水質は流入負荷の変動に対 する応答性が高く, 回帰式の傾きは最も大きい。一 方, 外海水による希䣋を受けやすく, 湾に直接流入 する負荷の割合が小さい西部海域では, 傾きは最も 小さい.

$\mathrm{T}-\mathrm{N}$ についても流入負荷量に対する水質濃度のば らつきはみられるものの, 流入負荷に対する海域別 の変動傾向は概ね $\mathrm{T}-\mathrm{P}$ と同様であった。

b) 内部生産効率との栄養塩類の関係（ $\triangle \mathrm{COD}$ 法に よる $a_{\mathrm{p}}$ と T-N/ T-P 比との関係)

次に, 式（1）により求めた内部生産効率 $\alpha_{\mathrm{p}}$ と $\mathrm{T}-\mathrm{N} / \mathrm{T}-\mathrm{P}$ 比の関係を図-7 に示す。なお，リン高度処 理導入後 $\left.(1999 \text { 年以降 })^{8)}, 18\right)$ の近年の関係性を把握 するため, ここでは 2003 年〜2009 年の海域別年平 均值を用いた。また, 公共用水域水質測定結果 ${ }^{9)}$ や 博多湾内の赤潮発生状況 ${ }^{22}$ をみると, 海域毎に発生 する赤潮構成種の違い等はみられず，各海域で発生 している赤潮の構成種に違いはなく, 栄養塩濃度の 多少と内部生産量の増減の関係は 3 つの海域で概ね 等しいと仮定し，海域別には分けずに，海域別の状 況を確かめた上で，3海域をまとめて内部生産効率 と $\mathrm{T}-\mathrm{N} / \mathrm{T}-\mathrm{P}$ 比の関係を導出した.

$a_{\mathrm{p}}$ と $\mathrm{T}-\mathrm{N} / \mathrm{T}-\mathrm{P}$ 比との関係は, 気象・海象による 変動や年々に発生する植物プランクトンの種の構成 の違い等によりばらつきはみられるものの, $\mathrm{T}-\mathrm{N} / \mathrm{T}-\mathrm{P}$ 比が高くなると内部生産効率が上昇する関 係が確かめられ，3 海域をまとめた相関では決定係 数がやや低いが正の関係がみられた。 T-N/T-P 比が 上昇した場合に内部生産効率が上昇する要因には, 次の 2 点が考えられる.

・栄養塩類の濃度や $\mathrm{T}-\mathrm{N} / \mathrm{T}-\mathrm{P}$ 比の変化に伴い植物 プランクトンの種組成が変化し， T-N/ T-P 比の 増加とともに内部生産効率 $\alpha_{\mathrm{p}}$ も増加した。

・栄養塩類濃度やその組成比によって生長の制限 を受ける植物プランクトンでは, 供給が限定さ 

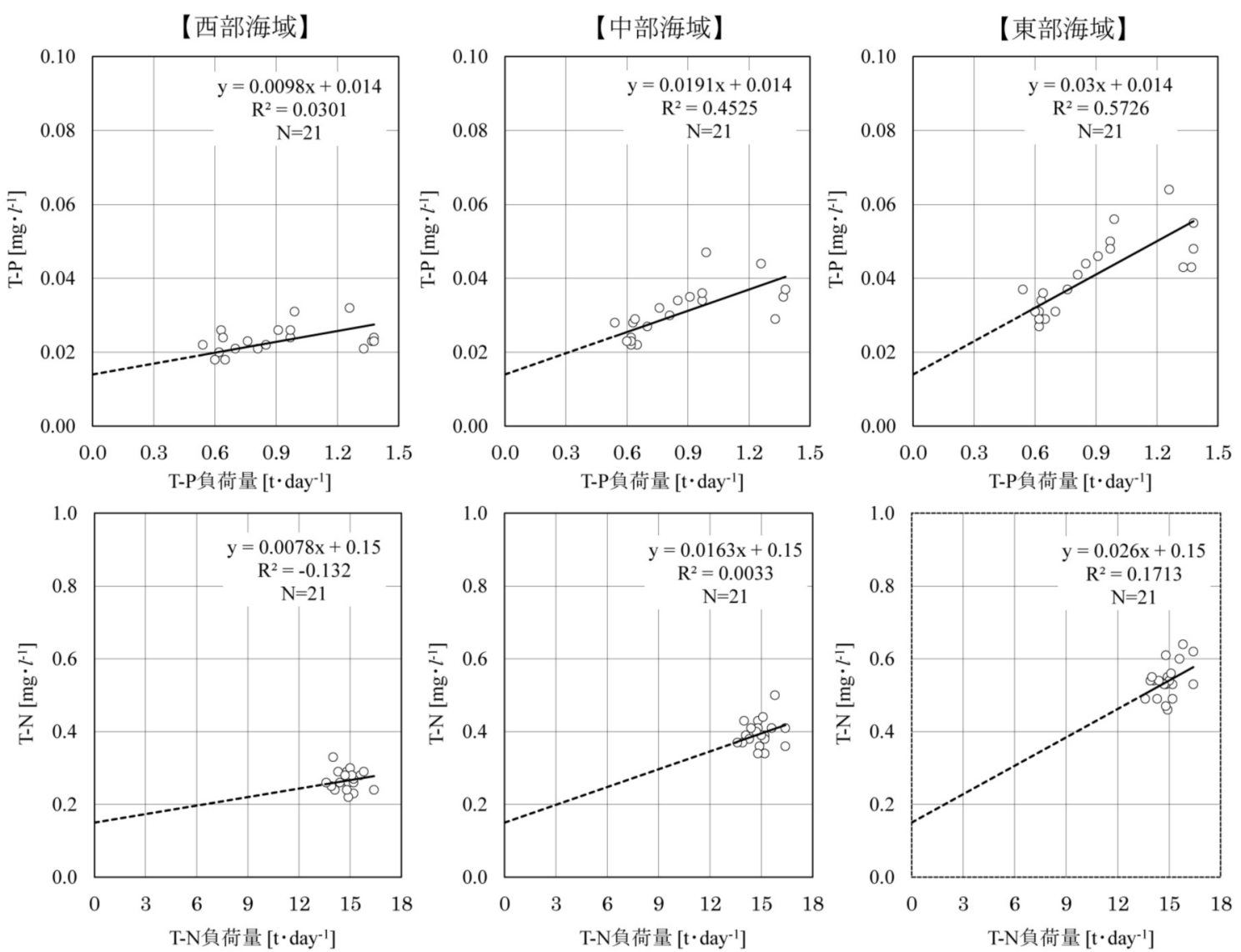

図-6 年平均流入負荷量と海域別年平均濃度の関倸（回帰直線の実線は算出に使用した負荷量範囲（負荷量の最小值〜 最大值）を，破線は範囲外（負荷量の最小值未満）を示す）

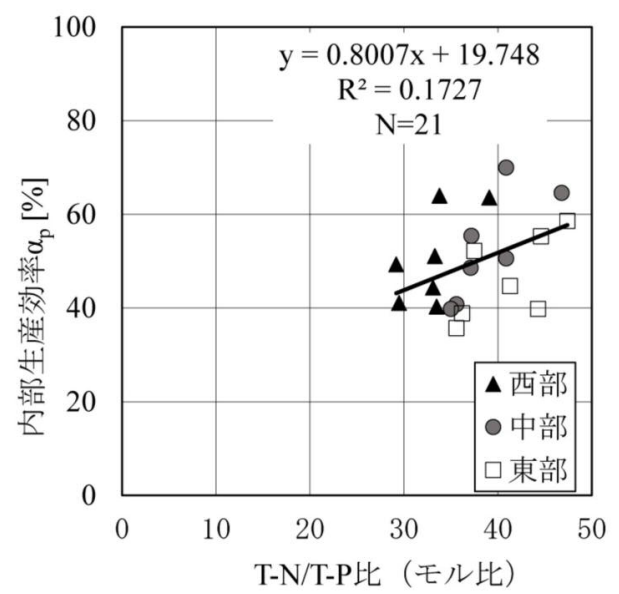

図-7 内部生産効率 $\alpha_{\mathrm{p}}$ と $\mathrm{T}-\mathrm{N} / \mathrm{T}-\mathrm{P}$ 比の関係

れているリンの細胞内含量に対して, 炭素量が 大きくなる。これは，プランクトンの炭素／窒 素比は生理学的に決まっているため, 窒素が豊 富にある場合には窒素をより多く取り込む“ぜ いたく消費”を起こし，窒素を多く取り込んだ分 だけ炭素も多くなるためである23)。これによ り, 植物プランクトンの一細胞あたりの炭素量, つまり COD 量が増えて, 内部生産効率 $\alpha_{\mathrm{p}}$ が上 昇したものと考えられる。

博多湾におけるリン濃度の経時的な減少に対し
て, COD の減少が小さい状況（図-2）は，上記の植 物プランクトンによる働きが一因であることが考え られる。

（2）夏季, 冬季の内部生産抑制の効果と許容量の検討 $\mathrm{T}-\mathrm{N}, \mathrm{T}-\mathrm{P}$ 流入負荷量と水質の関係, 内部生産効率 $a_{\mathrm{p}}$ と T-N/T-P 比の関係より求めたそれぞれの回帰 式, 及び式（1），（2）を用いて， T-P, T-N 流入負荷 量を変動させた場合の COD 濃度を試算し, T-N • $\mathrm{T}-\mathrm{P}$ 流入負荷量と COD の関係を整理した結果を図 -8 に示す。横軸は, 2005 2009 年度の季節別 (夏季： 6 8 月, 冬季：12〜2 月) の $\mathrm{T}-\mathrm{P}, \mathrm{T}-\mathrm{N}$ 流入負荷量に 対する試算に与えた流入負荷量の比である。図-8に 示している各海域の COD 環境基準值は，西部海域 と中部海域が $2 \mathrm{mg} \cdot l^{-1}$, 東部海域が $3 \mathrm{mg} \cdot l^{-1}$ である ${ }^{9)}$. また，両負荷量の変動を組み合わせ，環境基準值と の適合性を整理した結果を図-9に示す。なお，図-8 と図-9に示す試算結果に使用している回帰式は, 前 述のと抢り, 気象・海象による変動等に伴うばらつ きにより決定係数は低いものの，いずれも正の関係 がみられた。そそのため, 海域健全化に向けた栄養塩 類の夏季削減量, 冬季許容量の試算に必要な, COD の変動とその変動要因に起因する栄養塩類濃度の寄 

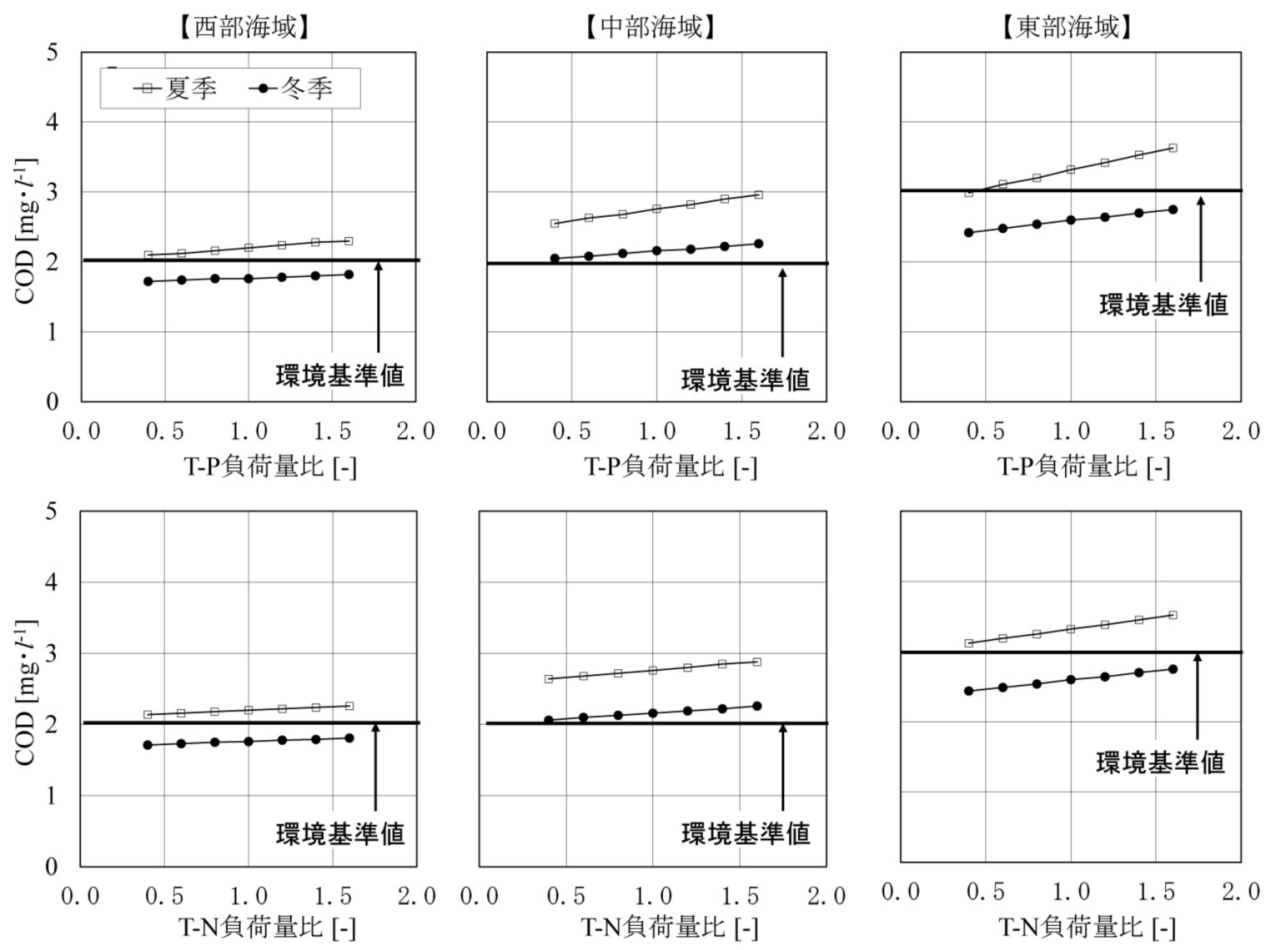

図-8 T-N，T-P 負荷量比と COD の関係

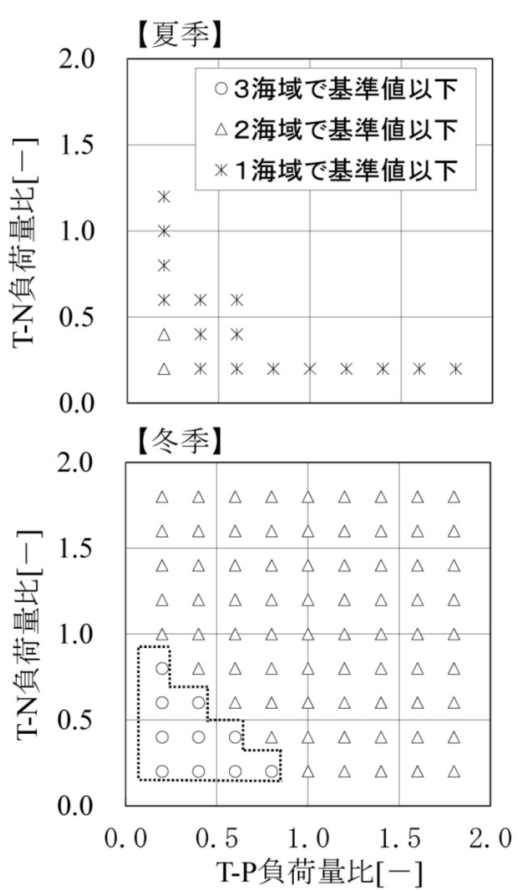

図-9 $\mathrm{T}-\mathrm{P} \cdot \mathrm{T}-\mathrm{N}$ 負荷量の変動と $\mathrm{COD}$ 基準超過の有無 (図 中の空白は 3 海域ともに基準値超過を示す)

与は概ね表現できていると考え，使用している．

夏季における $\mathrm{T}-\mathrm{P}$ 流入負荷量と COD の関係をみ ると, T-P 負荷量を半分 (負荷量比 0.5) とした場合, 低減する COD 濃度は, 西部海域で $0.08 \mathrm{mg} \cdot l^{-1}$, 中 部海域で $0.17 \mathrm{mg} \cdot l^{-1}$, 東部海域で $0.27 \mathrm{mg} \cdot l^{-1}$ と, 湾奥部の海域ほど効果的な改善傾向がみられた。こ の削減量は, P-COD 濃度の約 12\% (西部), 約 18\% (中部), 約 21\%（東部）にあたるものである。 $\mathrm{T}-\mathrm{N}$
流入負荷量と COD の関係について負荷量を半分と した場合も, 西部海域で $0.05 \mathrm{mg} \cdot l^{-1}(\mathrm{P}-\mathrm{COD}$ の約 $8 \%)$, 中部海域で $0.10 \mathrm{mg} \cdot l^{-1}$ ( $\mathrm{P}-\mathrm{COD}$ の約 $\left.11 \%\right)$, 東部海域で $0.17 \mathrm{mg} \cdot l^{-1}$ （P-COD の約 $13 \% ） の$ 低下 がみられた。このように栄養塩の流入負荷量削減 は, 夏季の海域 COD の改善に有効であるものと試 算された。

冬季においては, T-P 負荷量を 1.5 倍（負荷量比 1.5）とした場合, 増加する COD 濃度は西部海域で $0.06 \mathrm{mg} \cdot l^{-1}$, 中部海域で $0.08 \mathrm{mg} \cdot l^{-1}$, 東部海域で $0.11 \mathrm{mg} \cdot l^{-1}$ であった. $\mathrm{T}-\mathrm{P}$ 負荷量の増加に伴い内部 生産由来の $\mathrm{P}-\mathrm{COD}$ は増加するものの, 現状濃度で 環境基準值を上回っている中部海域を除くと, 西部 海域，東部海域では環境基準值を下回る状況を維持 していた。

しかしながら，T-N, T-P それぞれの負荷量削減の みで夏季及び冬季の全海域で COD の環境基準值を 下回ることは難しく, 両負荷量をともに変動させた 場合でも, T-N, T-P 流入負荷量がともに半分とした 場合に冬季が環境基準值以下となる状況であった。

このような現状の背景には, CODのうち, 内部生 産に由来しない $\mathrm{COD}(\mathrm{D}-\mathrm{COD})$ の占める割合が, 西 部海域で約 70\%，中部海域で約 68\%，東部海域で約 $65 \%$ と, 全 COD の多くを占めていること ${ }^{9)}$, 湾央部 に位置する中部海域の設定基準值が, 湾口部にあた る西部海域と同値であること孚が挙げられる. 


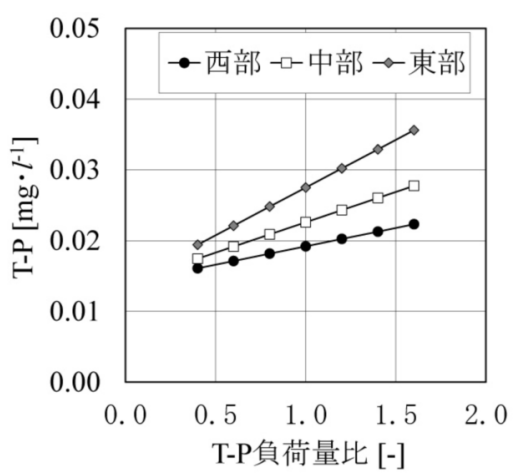

図-10 T-P 負荷量の変動と海域 $\mathrm{T}-\mathrm{P}$ の関係

表-1 $\mathrm{T}-\mathrm{P}$ 濃度の増分から推測される $\mathrm{PO}_{4}-\mathrm{P}$ 濃度の増分

\begin{tabular}{|l|c|c|c|}
\hline \multirow{2}{*}{\multicolumn{1}{|c|}{ 項目 }} & \multicolumn{3}{|c|}{ 海域 } \\
\cline { 2 - 4 } & 西部 & 中部 & 東部 \\
\hline \hline $\mathrm{T}-\mathrm{P}\left[\mathrm{mg} \cdot l^{-1}\right]$ & 0.018 & 0.024 & 0.033 \\
\hline $\mathrm{PO}_{4}-\mathrm{P}\left[\mathrm{mg} \cdot l^{-1}\right]$ & 0.006 & 0.008 & 0.014 \\
\hline $\mathrm{PO}_{4}$-P/T-P比 $[-]$ & 0.333 & 0.333 & 0.424 \\
\hline $\mathrm{T}-\mathrm{P}$ 増分 $\left[\mathrm{mg} \cdot l^{-1}\right]$ & 0.003 & 0.004 & 0.006 \\
\hline $\mathrm{PO}_{4}$-P増分 $\left[\mathrm{mg} \cdot l^{-1}\right]$ & 0.001 & 0.001 & 0.003 \\
\hline
\end{tabular}

\section{（3）冬季の生物生産の増加の効果}

冬季のノリ，ワカメ養殖は，図-4に示すとおり西 部海域, 中部海域を中心に行われている。水産用水 基準によると,ノリの生長に必要な $\mathrm{PO}_{4}-\mathrm{P}$ （リン酸 態リン: 無機態リン) 濃度は $0.007 〜 0.014 \mathrm{mg} \cdot l^{-124)}$, ワカメでは $0.006 \mathrm{mg} \cdot l^{-125)}$ といわれている。現状 の冬季の $\mathrm{PO}_{4}-\mathrm{P}$ 濃度は 2009 年度〜 2010 年度の層別 平均值で, 西部海域では $0.006 \mathrm{mg} \cdot l^{-1}$, 中部海域で は $0.008 \mathrm{mg} \cdot l^{-1}$ であり, 必要濃度の下限值あるいは 下限值以下となっている。

$\mathrm{T}-\mathrm{P}$ 負荷量を現状の 1.5 倍（負荷量比 1.5）に増や した場合, 図-10より, 海域の T-P 濃度は現状 (負荷 量比 1.0) と比較し, 西部海域で $0.003 \mathrm{mg} \cdot l^{-1}$, 中部 海域で $0.004 \mathrm{mg} \cdot l^{-1}$ の増加と予測される。 $\mathrm{T}-\mathrm{P}$ 濃度 増分が, 現在の $\mathrm{PO}_{4}-\mathrm{P} / \mathrm{T}-\mathrm{P}$ 比に比例して $\mathrm{PO}_{4}-\mathrm{P}$ 濃度 も増加すると仮定すると, 海域別の $\mathrm{PO}_{4}-\mathrm{P}$ 濃度の増 分は表-1に示すとおりとなる。これによると， T-P 負荷量を 1.5 倍に増やすと, 西部海域, 中部海域に おける $\mathrm{PO}_{4}-\mathrm{P}$ 濃度は $0.001 \mathrm{mg} \cdot l^{-1}$ 増加すると予測さ れた。この結果より， T-P 負荷量を 1.5 倍とするこ とで, 必要な $\mathrm{PO}_{4}-\mathrm{P}$ 濃度は下限值を下回ることはな く, 現状と比べて栄養塩類濃度を確保できるものと 試算される。

\section{4. まとめ}

- 博多湾への $\mathrm{T}-\mathrm{P}, \mathrm{T}-\mathrm{N}$ の流入負荷量と海域別 $\mathrm{T}-\mathrm{P}, \mathrm{T}-\mathrm{N}$ 濃度の関係は, 流入負荷量に比例して 変動しており，東部海域での水質は流入負荷の 変動に対する応答性が高く，西部海域は低い.

・内部生産効率 $\alpha_{\mathrm{p}}$ は, 海域によりばらつきはみら れるものの $\mathrm{T}-\mathrm{N} / \mathrm{T}-\mathrm{P}$ 比と概ね正の関係がみら れた。

・夏季の博多湾は, $\mathrm{T}-\mathrm{N}, \mathrm{T}-\mathrm{P}$ の負荷量削減による 海域 COD の低減効果が考えられた。

・冬季については， T-P 負荷量を 1.5 倍にするこ とで, 内部生産由来の COD は増加するものの, 現状濃度で環境基準值を下回っている西部海 域，東部海域では環境基準值を下回る状況が維 持でき，ノリ，ワカメの生長に必要なリン濃度 を確保しやすくなることが考えられた。

\section{5. おわりに}

本研究では，夏季における内部生産の抑制による 生物生息環境の保全, 冬季におけるノリやワカメを はじめとした生物生産の増加の 2 つを目標とし, 栄 養塩類負荷量の変動に伴う海域濃度変動の試算を 行った。

その結果, 内部生産の抑制は海域 COD の低減に 効果はみられるものの, 夏季の全海域, 冬季の一部 海域においては環境基準值を下回るものではなく, D-COD 抑制の検討や環境基準值の妥当性の検討が 必要と考えられるものであった。

また，冬季のノリ，ワカメ養殖生産については， $\mathrm{T}-\mathrm{P}$ 負荷量を現状の 1.5 倍程度に増加させることで 生育環境の改善効果がみられた。湾内に局所的に位 置するノリ, ワカメの養殖場水質は, 対象近傍での 負荷量配分の検討することでさらに効果的となるも のと考えられる。

ただし，これらの結果は，既存の現地調査結果か ら得られたデー夕を集計・解析し, 試算した結果で あり，各デー夕から解析した結果には関係性はみら れたものの，それぞれが有する気象・海象状況など, その他の要素から生じる変動から必ずしも有意な関 係が得られていないものもある。そのため, 今回得 られた結果から,「高度な栄養塩管理手法」の確立に 向けて, 今後は数值シミュレーションモデルを用い て，精緻化を図っていく考えである.

謝辞：本研究にあたっては福岡市の貴重なデータを 
使用した。ここに記し，感謝の意を表します。

\section{参考文献}

1）中西弘：閉鎖性内湾の貧栄養化問題について - 高度 な栄養盐管理, 環境と生物生産力との調和一, 水環境 学会誌, Vol. 34 (A), No. 2, p. 33, 2011.

2）山口峯生（吉田陽一編, 日本水産学会監修）：水域の窒 素：リン比と水産生物 水産学シリーズ 95, pp. 11-19, 恒星社厚生閣, 1993.

3）西島敏隆, 深見公雄 (吉田陽一編, 日本水産学会監修): 水域の窒素: リン比と水産生物 水産学シリーズ 95, pp. 20-28, 恒星社厚生閣, 1993.

4）環境省: 平成 23 年度第 2 回海域の物質循環健全化計 画検討委員会 資料 2 海域の健全性指標の検討，環境 省ホームページ https://www.env.go.jp/water/heisa/ healthyplan/conf/h23_002.html, 2011.

5）環境省：瀬戸内海環境保全基本計画，環境省ホーム ページ http://www.env.go.jp/press/100433.html, 2015.

6）福岡市環境局：博多湾環境保全計画, 福岡市ホーム ページ http://www.city.fukuoka.lg.jp/kankyo/k-chosei/hp/ keikaku4.html, 95pp, 2008.

7) 福岡県, 福岡市: 博多湾特定水域高度処理基本計画, 2002.

8）福岡市下水道局: 平成 5 11 年度福岡市水処理セン 夕一管理年報, 1994 2000.

9）福岡市環境局：福岡市水質測定結果報告書（平成元 $\sim 23$ 年度), 1991 2013.

10) Redfield et al. : RKR モデル, 1963.

11）日本海洋学会：有明海の生態系再生をめざして, 恒星 社厚生閣, 2005.

12）横山佳裕, 吉次祥子, 中嶋雅孝, 内田唯史, 中西弘 : 博多湾に抢ける栄養塩濃度の変化に伴う植物プラン クトンの種の変化の解析, 土木学会論文集 B3 (海洋開 発), Vol. 67, No. 2, pp. I_340-I_345, 2011.

13）㴊上哲：博多湾の栄養塩環境とノリ養殖, 特集 海の貧 栄養化とノリ養殖, 海洋と生物, Vol. 31, No. 2, pp. 171-172, 2009.

14）福岡市農林水産局：福岡市水産業総合計画, 福岡市
ホームページ http://www.city.fukuoka.lg.jp/nosui/ suisanshinko/ shisei/ fukuokasshisuisangyosougoukeikaku. html, 2012.

15）横山佳裕, 中野裕香子, 吉次祥子, 中嶋雅孝, 内田唯 史，中西弘：閉鎖性水域に対する高度な栄養塩管理の 導入に関する一考察, 土木学会論文集 G (環境), Vol. 67, NO. 7, pp. III_203-III201，2011.

16）福岡市道路下水道局: 下水道の水質, 福岡市道路下水 道局ホームページ http://www.city.fukuoka.lg.jp/doro-ges uido/suishitsu/hp/01/index.html, 2010.

17）福岡市環境局：博多湾に係る施策・調查結果（平成 24 年度調查結果), 福岡市ホームページ http://www.city.fu kuoka.lg.jp/kankyo/k-chosei/hp/ sizenkankyou/ hakatawan. html, 2013.

18）気象庁：過去の気象デー夕検索, 気象庁ホームページ http://www.data.jma.go.jp/obd/stats/etrn/index.php, 2011.

19）国土交通省計画局：国土数值情報ダウンロードサービ ス，国土交通省ホームページ http://nlftp.mlit.go.jp/ksj/， 2010.

20）中西弘, 浮田正夫, 宇野良治：海域に扔ける COD 生産 について, 用水と廃水, Vol. 24, No. 6, pp. 43-46, 1976.

21） T. R. Persons, 高橋正征, B. Hargrave : 生物海洋学 2 粒 状物質の一次生成（高橋正征, 古谷研, 石丸隆監訳), pp. 61-72, 東海大学出版会, 1996.

22）水産庁九州漁業調整事務所：九州海域の赤潮（平成元 年 平成 24 年), $1990 \sim 2013$.

23) T. R. Persons, 高橋正征, B. Hargrave : 生物海洋学 $17^{\circ}$ ランクトンの分布/化学組成 (高橋正征, 古谷研, 石丸 隆監訳), pp. 59-72, 東海大学出版会, 1996.

24）社団法人 日本水産資源保護協会 : 水産用水基準 第 7 版（2012 年版）, p. 16, 社団法人日本水産資源保護協 会, 2013.

25）江藤拓也, 片山幸恵, 江崎恭志：2008 年から 2010 年 に扮ける福岡湾でのノリ, ワカメ養殖の不作要因につ いて, 福岡県水産海洋技術センター研究報告, 第 22 号, 2012.

(2015. 8. 10 受付) 


\title{
A STUDY ABOUT THE INTRODUCTION OF ADVANCED MANAGEMENT OF NUTRIENTS FOR HAKAKA BAY
}

\author{
Yuuya GOTOU, Yoshihiro YOKOYAMA, Tadashi UCHIDA and Masataka \\ NAKASHIMA
}

In order to study the management of nutrients for the harmony of two phenomenon, the one was the conservation of biological habitation due to control of the primary production in summer, the other was the healthiness of biological production such as Nori laver and seaweed cultivation in winter, we were calculated the variations of water quality due to the change of nutrient loads in Hakata Bay. As a result, in summer, the reduction of T-P loads were showed the effects of the primary production control and the decrease of COD concentration in the bay. In winter, COD derived from primary production was increased by increasing T-P loads of 1.5 times, but COD in the western and eastern area in the bay that were equal to or less than the environmental standards in status quo were preserved the following environmental standards value. Forhermore, the increase of T-P loads of 1.5 times was showed the effect of the improving the habitation of Nori laver and seaweed cultivation. 